\title{
Author Correction: Membrane-binding and activation of LKB1 by phosphatidic acid is essential for development and tumour suppression
}

Giada Dogliotti, Lars Kullmann, Pratibha Dhumale, Christian Thiele, Olga Panichkina, Gudrun Mendl, Roland Houben, Sebastian Haferkamp, Andreas W. Püschel \& Michael P. Krahn

Correction to: Nature Communications https://doi.org/10.1038/ncomms15747, published online 26 June 2017.

This Article contains an error in Supplementary Fig. 6a. In Supplementary Fig. 6a the actin bands are inadvertently duplicated from the S6K bands.
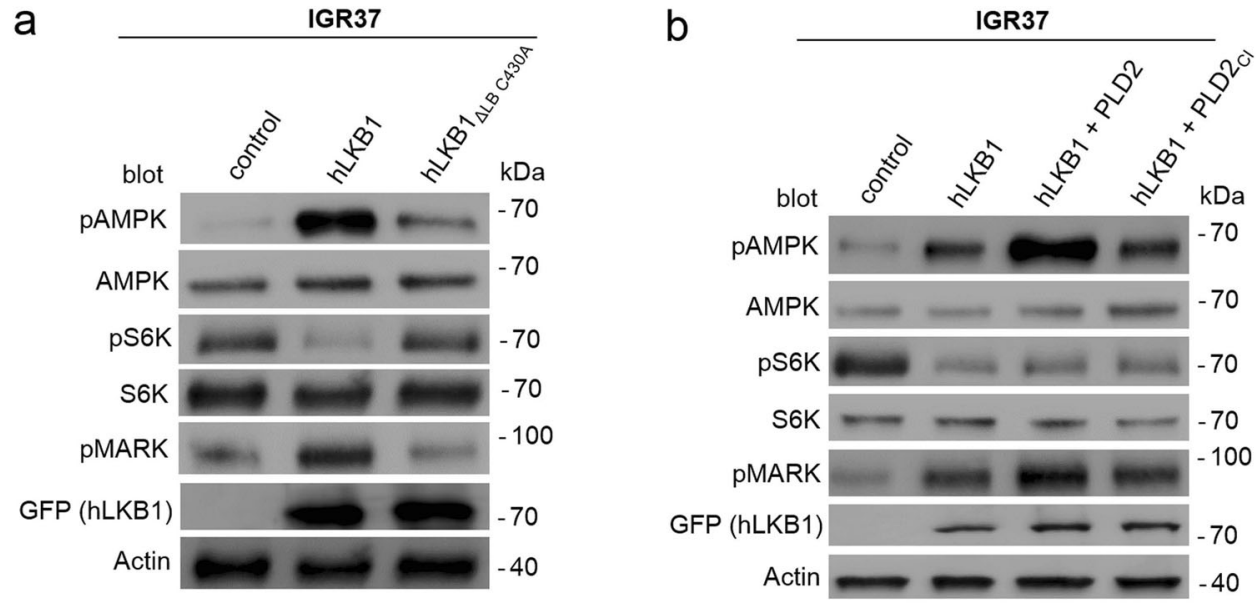

C

Cell viability $(\%)-12 \mathrm{~h}$ AICAR

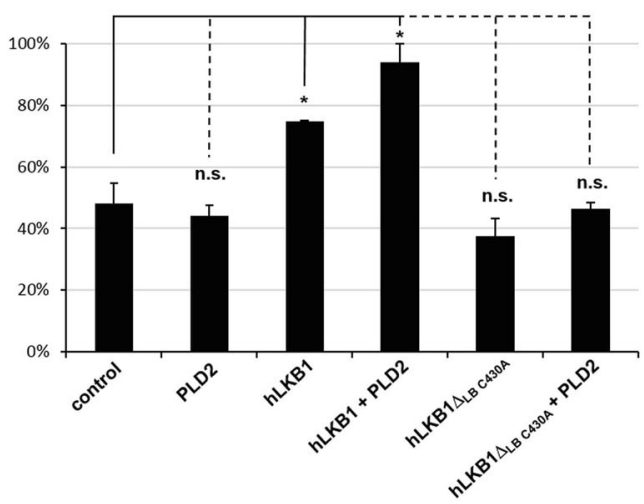


The incorrect bands have now been replaced and are shown below.

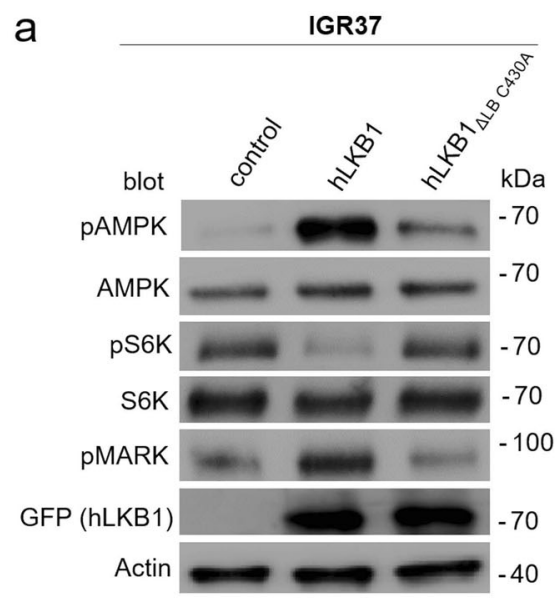

C

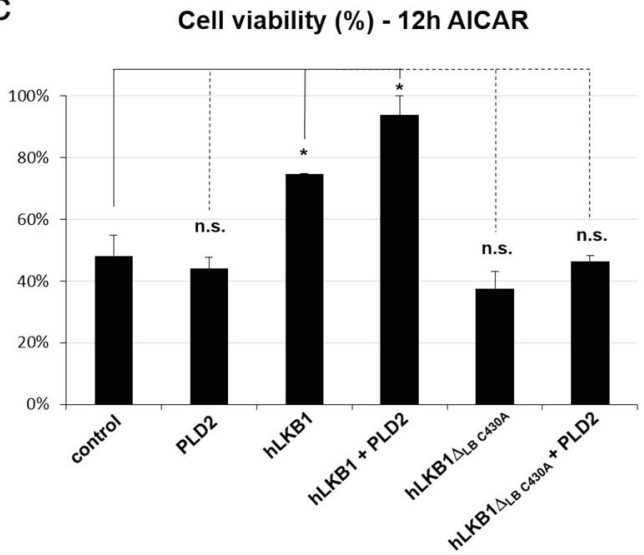

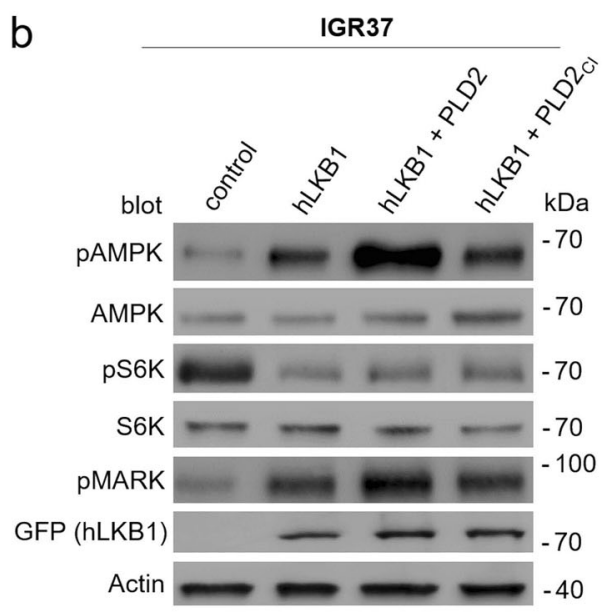

In addition, this Article was published without a Supplementary Figure containing full blots for all of the blots shown in the Figures and Supplementary Figures. A figure containing the full blots, Supplementary Fig. 7, has been added to the appended Supplementary Information file.

Published online: 08 March 2022

\section{Additional information}

Supplementary information The online version contains supplementary material available at https://doi.org/10.1038/s41467-022-28923-3.

(c) Open Access This article is licensed under a Creative Commons Attribution 4.0 International License, which permits use, sharing, adaptation, distribution and reproduction in any medium or format, as long as you give appropriate credit to the original author(s) and the source, provide a link to the Creative Commons license, and indicate if changes were made. The images or other third party material in this article are included in the article's Creative Commons license, unless indicated otherwise in a credit line to the material. If material is not included in the article's Creative Commons license and your intended use is not permitted by statutory regulation or exceeds the permitted use, you will need to obtain permission directly from the copyright holder. To view a copy of this license, visit http://creativecommons.org/licenses/by/4.0/.

(c) The Author(s) 2022 